\title{
ANALYSIS OF LIFE SATISFACTION OF STUDENTS STUDYING AT THE FACULTY OF SPORTS SCIENCES ACCORDING TO DIFFERENT VARIABLES
}

\author{
Levent Bayram, \\ Deniz Özge Yüceloğlu Keskin \\ Ondokuz Mayıs University, \\ Yaşar Doğu Sport Sciences Faculty, \\ Samsun, Turkey
}

\begin{abstract}
:
The aim of this study is to examine the general life satisfaction levels of university students in terms of age, gender, perceived level of welfare and the state of doing physical activity. The study was conducted on 159 students studying at Ondokuz May1s University Faculty of Sports Sciences. The data were obtained by using Adult Life Satisfaction Scale and Personal Information Form. T test, Kruskal Wallis Test and One Way Anova were used in the analysis of data. According to the results of the study, it was found that life satisfaction levels were higher in women, in students who exercised regularly and in those who had higher level of income, while it did not differ in terms of the variable of age.
\end{abstract}

Keywords: life satisfaction, university students, sports sciences

\section{Introduction}

Nowadays, it has been observed that researches in the field of positive psychology have concentrated on topics such as hope, happiness, optimism, forgiveness, well-being and subjective well-being (Gable \& Haidth, 2005). Positive psychology advocates an understanding that it is not enough to improve the negative situations (such as disease) encountered by the individual in life, but it is also important to develop the positive characteristics that the individual has (such as love, sensitivity, ability and specificity) (Seligman, 2002). In this understanding, efforts to improve the strengths of the individual rather than eliminating deficiencies or weaknesses have come to the fore and it is emphasized that this orientation will be more effective in preventing psychopathology (Suldo and Huebner, 2004).

In positive psychology, the term "subjective well-being" is usually used as the conceptual equivalent of happiness. Subjective well-being includes three interrelated

'Correspondence: email levent.bayram@omu.edu.tr 
factors: positive affect, negative affect and life satisfaction. While positive and negative affect consist of pleasant and unpleasant emotions, life satisfaction includes cognitive assessments relating an individual's life. High positive affect and perceived life satisfaction also mean high subjective well-being (Diener and Suh, 1997).

The concept of life satisfaction was first defined by Neugarten et al. (1961) (Neugarten et al., 1961). Satisfaction is the fulfilment of expectations, needs, desires and wishes. "Satisfaction with life" is the situation or result obtained by comparing individuals' expectations (what they want) with what they have. In other words, it expresses the result that occurs with the comparison of individuals' expectations with the real situation (Özer and Karabulut, 2003). Life satisfaction is the situation or result obtained from the comparison of individuals' expectations and what they have. This is the individual's general attitude towards life (Haybron, 2004). Life satisfaction is an individual's emotional response (or attitude) towards life, which is defined as work, leisure and other non-work time (Dikmen and Alpay, 1995).

While some researchers have considered life satisfaction as subjective well-being, others have considered it as happiness (Özer and Karabulut, 2003). In general definitions, while positive evaluations are associated with happiness, negative evaluations are associated with depression and unhappiness (Proctor et al., 2008). It is stated that the motivation to feel physically well, to be happy, to find meaning in life and to reach goals in daily life affects life satisfaction with positive identity, economic level, feeling secure and satisfying relationships (Ünal, 2013).

Individuals with high life satisfaction are expected to:

- feel happy with daily life activities,

- be aware that life has a meaning, find goals in life and be aware of the responsibility of the past life,

- have the belief that they have reached the goals they have foreseen during their lives,

- have a positive image of "self" and consider themselves as a valuable being regardless of their weaknesses,

- have a positive attitude towards life in general (Ümmet, 2012).

The aim of our study is to examine the life satisfaction of students studying at the Faculty of Sports Sciences in terms of different variables (gender, age, level of income, state of exercising regularly).

\section{Material and Methods}

The sample of the study consists of a total of 159 university students, 57 female and 102 males, studying at Ondokuz Mayıs University, Faculty of Sports Sciences. Ages of the participants varied between 18 and 26. In our study, Adult Life Satisfaction Scale (ALSS) was used to find out the life satisfaction of students. In the personal information form prepared for the study, university students were asked demographic questions such as age, gender, the state of exercising regularly and perceived level of income. The survey 
was delivered to the participants via the internet. Google Forms application was used for this. Google survey link was shared in the classrooms and student groups university students formed on the internet and students were invited to participate in the study. Participants who approved the voluntary consent form participated in the study knowing that they could quit whenever they liked. The simplified version of the scale was developed by Diener, Emmons, Larsen and Griffin in 1985. The short form has a single factor and includes 5 items. Turkish version of the Adult Life Satisfaction Scale consists of 21 items. It has a 5-factor structure; the first factor measures general satisfaction with life, the second factor measures relationship satisfaction, the third factor measures self-satisfaction, the fourth factor measures social environment satisfaction and the fifth factor measures job satisfaction. The scale is rated as 1 "not suitable at all" and 5 "completely suitable". The minimum possible score from the scale is 21 , while the maximum possible score is 105 . Cronbach Alpha internal consistency coefficient was found as .89 . As a result of test reliability studies, correlation coefficient was found as $\mathrm{r}=.891$. Within the scope of these results, adult form has been used as a valid and reliable measurement tool (Kaba et al., 2018).

The data collected with survey forms was uploaded in the computer by using coding method. The data in the computer environment was processed and analyzed in accordance with the purposes of the study. Descriptive statistics, arithmetic means (X) and standard deviations (SD) of the data obtained were calculated. SPSS 22 (Statistical Packages for the Social Sciences) computer program was used in data analysis. T Test, Kruskal Wallis Test and One Way Anova test were used in the analysis and interpretation of the data. Significance was taken as $\mathrm{p}<0.05$.

\section{Results}

Table 1: Life satisfaction levels of students in terms of gender

\begin{tabular}{|l|c|c|c|c|c|}
\hline Gender & N & Ort & Ss & t & p \\
\hline Female & 57 & 77.83 & 77.82 & 2.38 & \multirow{2}{*}{$0.019^{*}$} \\
\hline Male & 102 & 73.25 & 73.25 & 2.45 & \\
\hline
\end{tabular}

Life satisfaction levels were found to differ significantly with a mean score of 77.83 in female students and with a mean score of 73.25 in male students $(p>0.05)$.

Table 2: Life satisfaction levels of students in terms of age

\begin{tabular}{|l|c|c|c|c|c|c|c|}
\hline Age & N & Ort & Ss & Med & Min & Maks & p \\
\hline $18-20$ & 90 & 73,31 & 11,52 & 73 & 43 & 104 & \multirow{2}{*}{0.090} \\
\cline { 1 - 8 } $21-23$ & 40 & 77,82 & 11,75 & 78 & 57 & 104 & \\
\hline $24-26$ & 20 & 74,85 & 12,36 & 79 & 50 & 89 & \\
\hline
\end{tabular}

According to Table 2, life satisfaction levels did not differ significantly in terms of the variable of age. 
Table 3: Life satisfaction levels of students in terms of perceived level of income

\begin{tabular}{|l|c|c|c|c|}
\hline Income & $\mathbf{N}$ & Ort & Ss & p \\
\hline Low & 44 & 68,93 & 10,95 & \multirow{2}{*}{$.000^{*}$} \\
\hline Mid & 84 & 76,63 & 10,89 & \\
\hline High & 31 & 78,65 & 12,58 & \\
\hline
\end{tabular}

As can be seen in Table 3, significant difference was found in life satisfaction levels of students in terms of perceived level of income and life satisfaction level increased as level of income increased $(\mathrm{p}>0.01)$.

Table 4: Life satisfaction levels of students in terms of the state of exercising regularly

\begin{tabular}{|l|c|c|c|c|c|}
\hline Exercises & $\mathbf{N}$ & Ort & Ss & $\mathbf{t}$ & $\mathbf{p}$ \\
\hline No & 113 & 768.850 & 1.206 .141 & 3.449 & \multirow{2}{*}{$.001^{*}$} \\
\hline Yes & 46 & 70.000 & 961.480 & 3.792 & \\
\hline
\end{tabular}

According to Table 4, life satisfaction levels of students who exercised regularly were found to be significantly higher than those of the students who did not $(p>0.01)$.

\section{Discussion}

In the study, life satisfaction was discussed in terms of gender and significant difference was found between life satisfaction levels in favour of female students $(p=0.019)$. Female students were found to have higher life satisfaction levels than male students. Soyer et al. (2017), Altuntaş (2019), Gündoğar et al. (2007) and Çivitçi (2012) examined life satisfaction of university students and they did not find any significant difference between genders. Yazıcı and Kumcağız reported that life satisfaction levels of male university students were higher than those of female university students.

It was concluded that there was no significant difference between life satisfaction levels in terms of age, which is another variable of the study. The result obtained was in parallel with Altuntaş (2019)'s study. Gündoğar et al. (2007) found significant difference between age groups in terms of life satisfaction levels.

In terms of the state of participating in sports activities, it was found that life satisfaction levels of university students who reported exercising regularly differed highly significantly than those of students who did not $(p=0.001)$. Similarly, Soyer et al. (2017) found a significant difference of .05 in life satisfaction levels in terms of regular participation in sports activities. Polat (2014) concluded that participating in social activities affected life satisfaction positively.

According to our results, significant difference was found between students who had low, moderate and high levels of income. It was found that life satisfaction increased as level of income increased. This result is in parallel with the results of Çetinkaya (2011), Gündoğar (2007), Chow (2005), Özgür (2010) and Tuzgöl Dost (2007) that individuals with high level of welfare also have high life satisfaction. Soyer et al. (2017) also found 
that life satisfaction levels of students increased as their perceived level of welfare increased.

\subsection{Recommendations}

Directing university students to more physical activity will help increase their life satisfaction levels. Improving the financial opportunities of students and including them in free social activities will contribute positively to their life satisfaction.

\section{Conflict of Interest Statement}

The authors declare no conflicts of interests.

\section{About the Authors}

Dr. Levent Bayram is a lecturer at Ondokuz Mayıs University Yaşar Doğu Sport Sciences Faculty, Turkey.

Dr. Deniz Özge Yüceloğlu Keskin is a lecturer at Ondokuz Mayıs University Yaşar Doğu Sport Sciences Faculty, Turkey.

\section{References}

Altuntaş, Y. (2019). Üniversitelerin Tenis Oynayan Beden Eğitimi Ve Spor Bölümü Öğrencilerinin Özgüven Düzeylerinin Yaşam Doyumu ve Yaşam Kalitesine Etkisi. Marmara Üniversitesi Sağlık Bilimleri Enstitüsü.

Chow, H. P. H. (2005). Life satisfaction among university students in a Canadian prairie city: a multivariate analysis. Soc Indic Res, 70, 139-150.

Çetinkaya, E. (2011). Emekli bireylerde yaşam doyumunun yordayıcıları olarak sosyal destek ve özyeterlilik. Yayınlanmamış Yüksek Lisans Tezi, Hacettepe Üniversitesi Sosyal Bilimler Enstitüsü, Ankara.

Çivitçi, A. (2012). The Relationships Between Global Life Satisfaction and Psychological Needs in University Students, Ç.Ü. Sosyal Bilimler Enstitüsü Dergisi, 21(2), 321336

Diener, E., Suh, E. (1997). Measuring quality of life: Economic, social, and subjective indicators. Social Indicators Research, 40, 189-216.

Dikmen, Ahmet Alpay (1995). "İş doyumu ve yaşam doyumu ilişkisi" Ankara Üniversitesi SBF Dergisi 50.03

Gable, S. L., Haidth, J. (2005). What (and why) is positive psychology? Review of General Psychology, 9(2), 103-110.

Gündoğar, D. et al. (2007). Investigation of the Predictors of Life Satisfaction in University Students. 10,14-27.

Haybron D. M. (2004). Happiness and The Importance of Life Satisfaction. Delivered at the Department of Philosophy, 20. 
Kaba, İ., Erol, M., Güç, K. (2018). Development of Adults Life Satisfaction Scale. Anadolu University Journal of Social Sciences, 18(1), 1-14.

Neugarten, B. L. et al. (1961). The Measurement of the Life Satisfaction, Journal of Gerontology, 16, 134-143.

Özer, M., Karabulut, Ö. (2003). Satisfaction of Life in Elderly Individuals. Geriatri, 6(2),7274.

Özgür, G., Babacan Gümüş, A., Durdu, B. (2010). Life Satisfaction of University Students Living at Home or in the Dormitory. Journal of Psychiatric Nurses 1(1):25-32.

Polat, A. (2014). Egzersiz yapan ve yapmayan emniyet mensuplarının yaşam doyumu iş tatmini ve tükenmişlik düzeylerinin incelenmesi (Sakarya İli Örneği), Yüksek Lisans Tezi, Sakarya Üniversitesi Eğitim Bilimleri Enstitüsü, Sakarya.

Proctor, C. L., Linley, P. A., \& Maltby, J. (2009). Youth life satisfaction: A review of the literature. Journal of Happiness Studies: An Interdisciplinary Forum on Subjective Well-Being, 10(5), 583-630.

Seligman, M. E. (2002). Positive psychology, positive prevention, and positive therapy. (In Snyder, C.R.; S. J. Lopez) (Eds.). Handbook of Positive Psychology (pp. 3-9). New York: Oxford University Press. [Electronic version]. Retrieved February 02, 2006.

Soyer, F., Yıldız, N. O., Harmandar Demirel, D., Serdar, E., Demirel, M., Ayhan, C., Demirhan, Ö. (2017). The investigation of the relationship between the factors that revent university students from attending to the recreational activities and the life satisfaction of the participants. Journal of Human Sciences, 14(2), 2035-2046.

Suldo, S. M., Huebner, E. S. (2004). Does life satisfaction moderate the effects of stressful life events on psychopathological behavior during adolescence? School Psychology Quarterly, 19 (2), 93-105.

Tuzgöl Dost, M. (2007). Examining Life Satisfaction Levels of University Students in Terms of Some Variables. Pamukkale Üniversitesi Eğitim Fakültesi Dergisi, 22, 132-143.

Ümmet, D. (2012). Üniversite Öğrencilerinde Özgecilik Davranışının Transaksiyonel Analiz Ego Durumları ve Yaşam Doyumu Bağlamında İncelenmesi. Doktora Tezi, Marmara Üniversitesi, Eğitim Bilimleri Enstitüsü, İstanbul

Ünal, A. Ö., Şahin, M. (2013). A Prediction of Life Satisfaction of High School Students According to Some Variables. Cumhuriyet International Journal of EducationCIJE. 2(3), 46-63. 
Creative Commons licensing terms

Authors will retain the copyright of their published articles agreeing that a Creative Commons Attribution 4.0 International License (CC BY 4.0) terms will be applied to their work. Under the terms of this license, no permission is required from the author(s) or publisher for members of the community to copy, distribute, transmit or adapt the article content, providing a proper, prominent and unambiguous attribution to the authors in a manner that makes clear that the materials are being reused under permission of a Creative Commons License. Views, opinions and conclusions expressed in this research article are views, opinions and conclusions of the author(s). Open Access Publishing Group and European Journal of Special Education Research shall not be responsible or answerable for any loss, damage or liability caused in relation to/arising out of conflict of interests, copyright violations and inappropriate or inaccurate use of any kind content related or integrated on the research work. All the published works are meeting the Open Access Publishing requirements and can be freely accessed, shared, modified, distributed and used in educational, commercial and non-commercial purposes under a Creative Commons Attribution 4.0 International License (CC BY 4.0). 